NOTAS

\title{
A MILAGROS CON CARIÑO, RESPETO Y PROFUNDA ADMIRACIÓN
}

Ma. Julia Sierra*

La tarea de todo maestro, como nos dice Gusdorf, refiriéndose a Sócrates, es la de "ser partero de espíritus"1. Despertar a las conciencias que se ignoran a sí mismas y guiarlas para que sean capaces de lograr su propia realización. Toda lección es siempre una lección de humanidad, la intervención del maestro no es más que el desvelamiento del ser humano. Cada clase consagra uno de los momentos más importantes y misteriosos de la existencia humana. En el diálogo entre el profesor y el alumno, gracias a la eficacia del encuentro, una vida cambia, pero no a semejanza de la vida que la visitó, sino a su propia y singular semejanza; ahora se conoce,

* Departamento Académico de Estudios Generales, ITAM.

${ }^{1}$ Georges Gusdorf, ¿Para qué los profesores?, 1969, Madrid, Cuadernos para el Diálogo, p. 13. se pertenece y se sabe responsable de su propia realización.

La vocación de Milagros Mier fue el Magisterio. Su pasión fue enseñar a pensar. Hoy, algunos de sus alumnos nos hablan de las huellas que Milagros les imprimió.

Numerosos alumnos y ex alumnos presentaron sus escritos, a continuación publicamos algunos escogidos: 